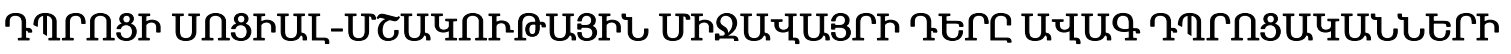

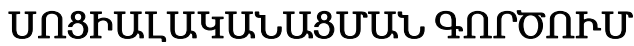

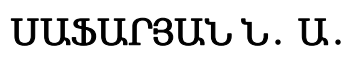

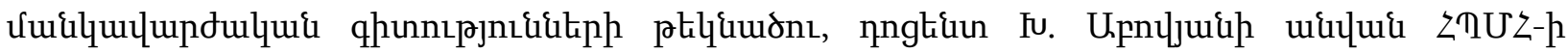

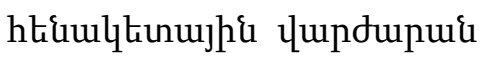

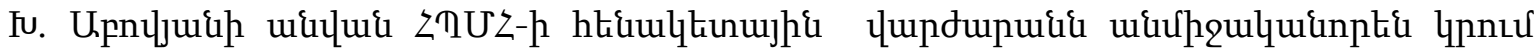

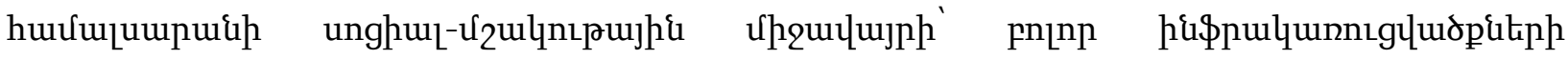

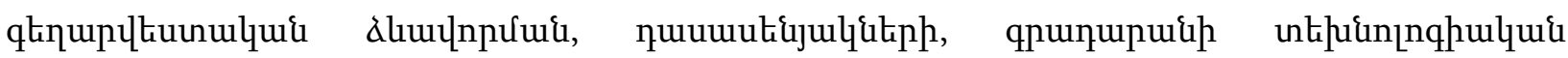

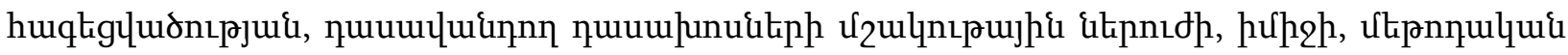

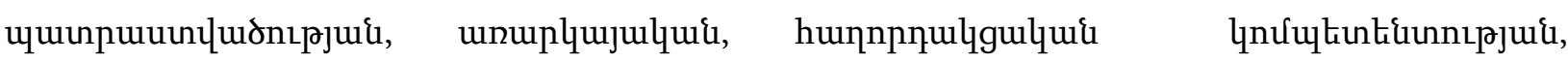

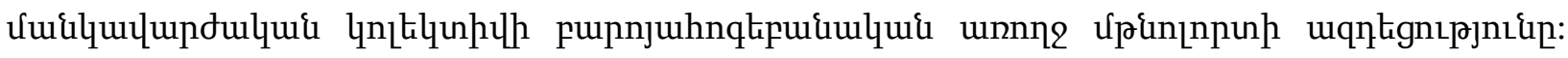

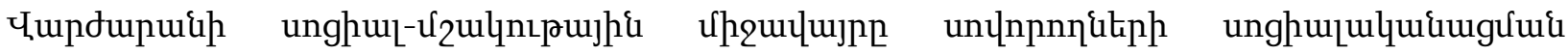

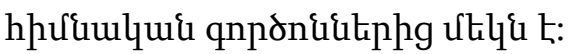

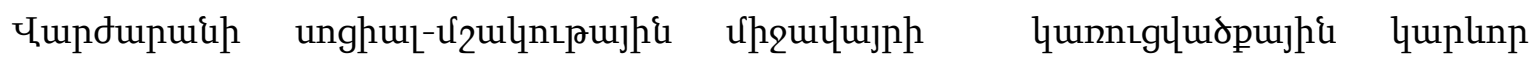

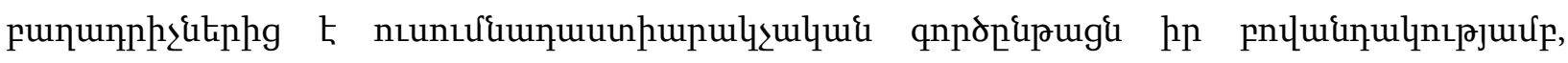
quqưulıрư

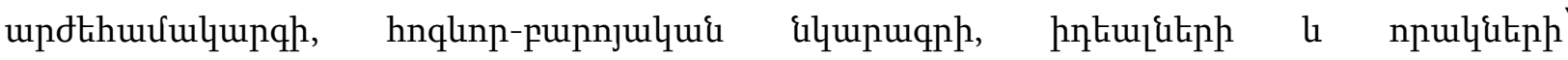

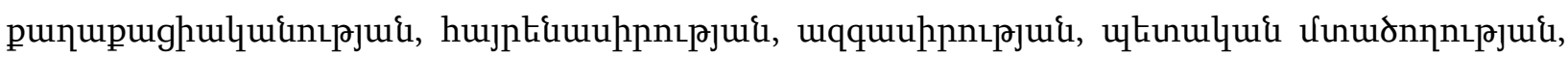

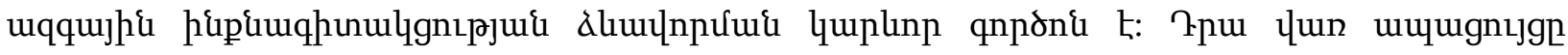

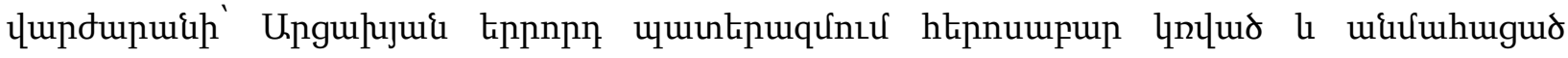

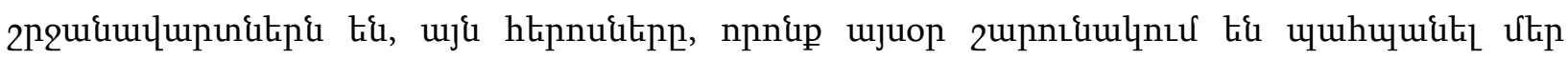

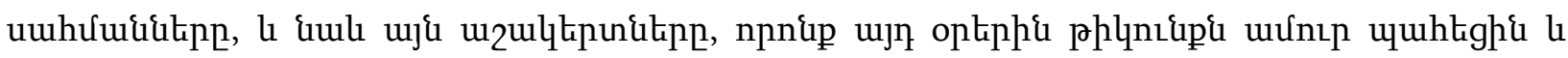

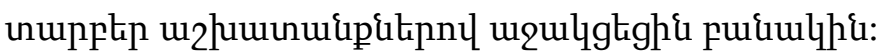

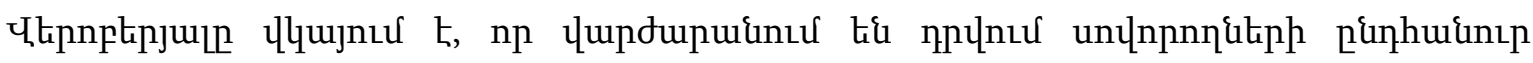

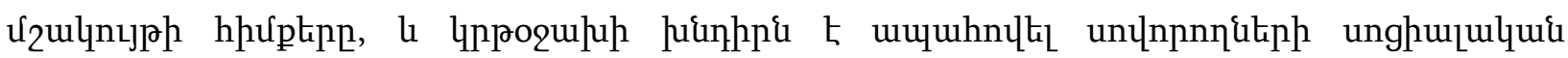

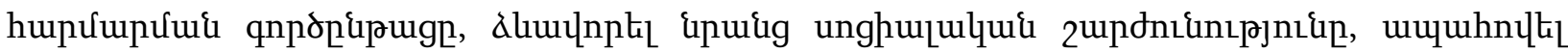

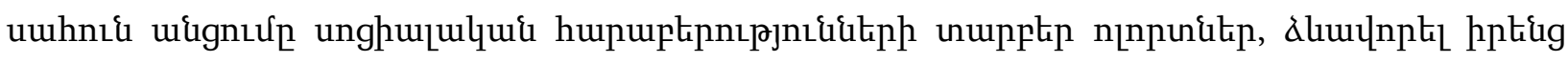

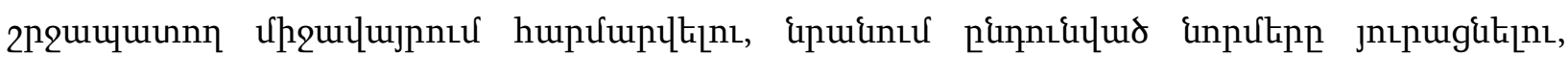

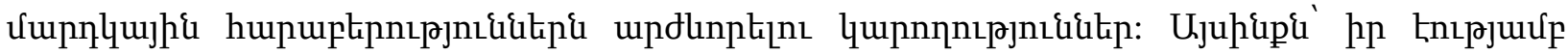

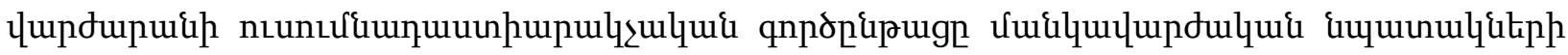

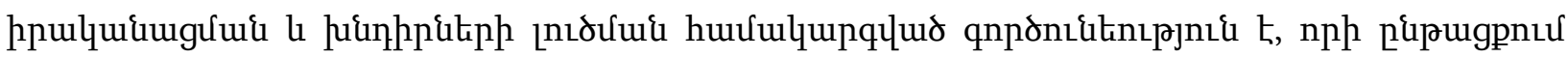




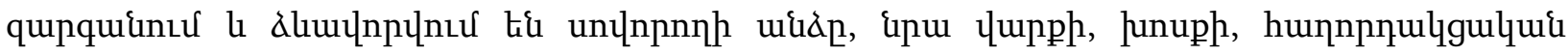

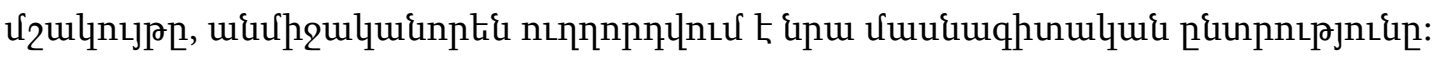

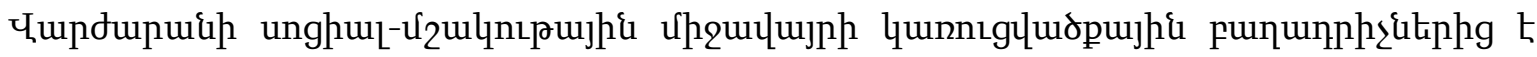

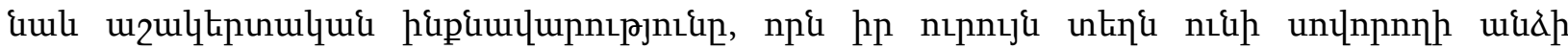

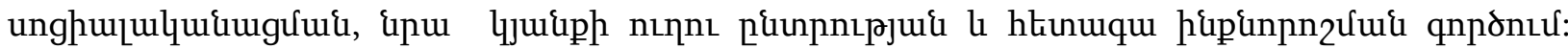

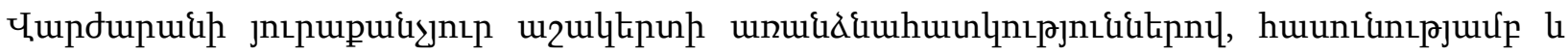

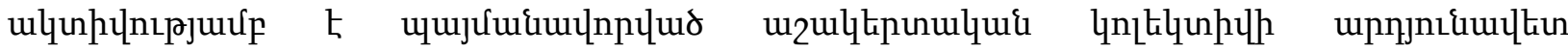
unghüulquilumgnıú:

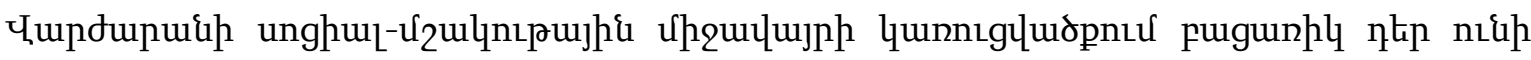

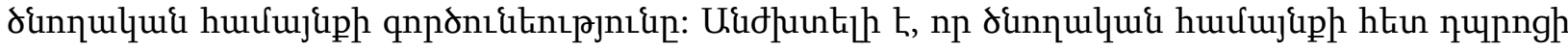

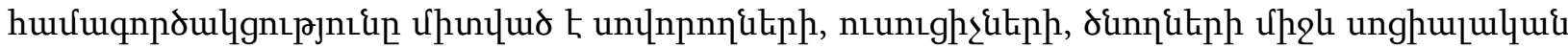

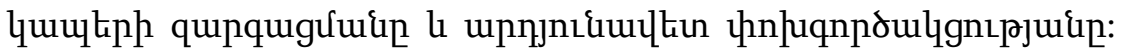

Cuin U. Ltinqunlip

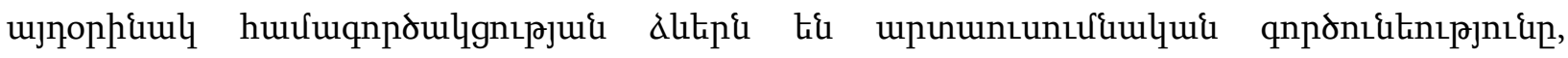

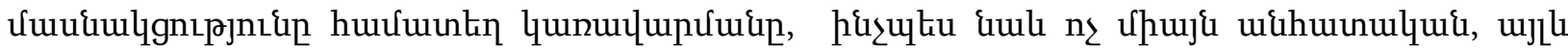

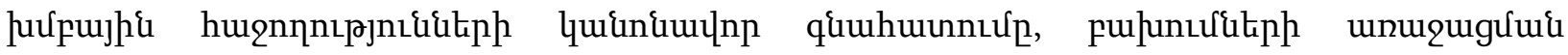

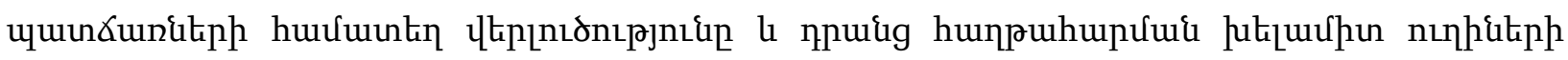
npnunuर्u [3, tq 103-104]:

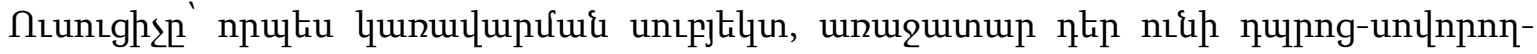

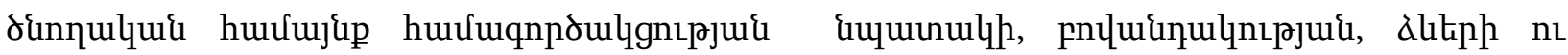

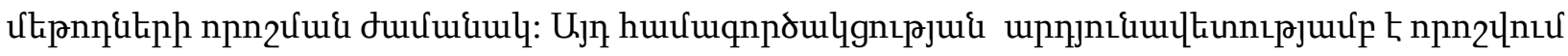

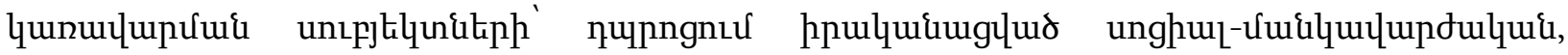

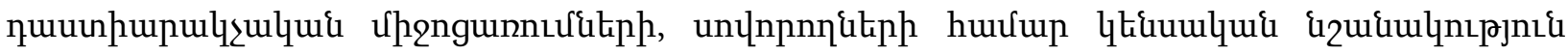

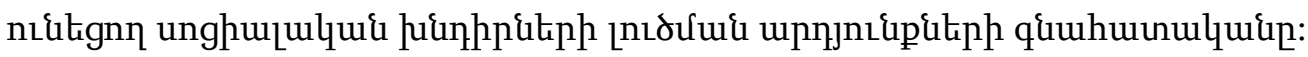

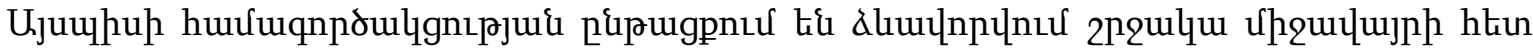

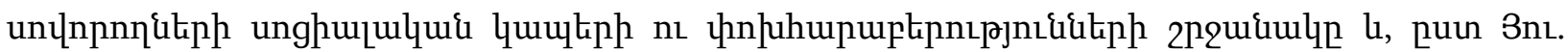

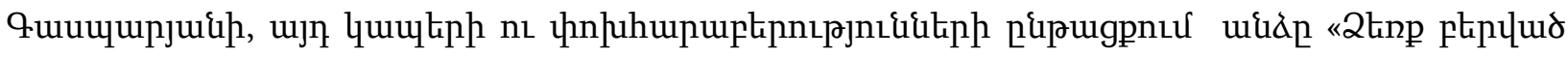

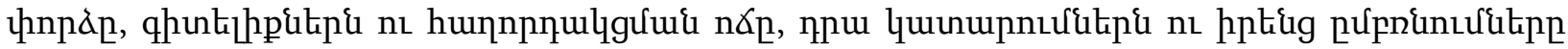

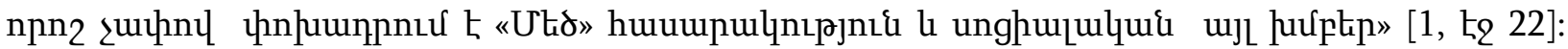

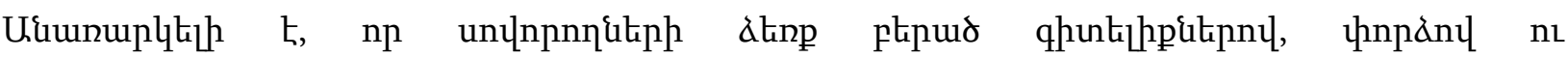

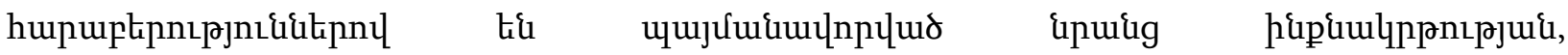

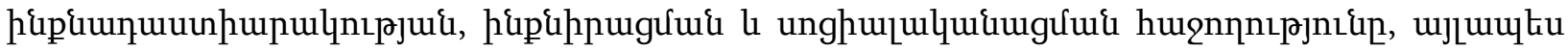

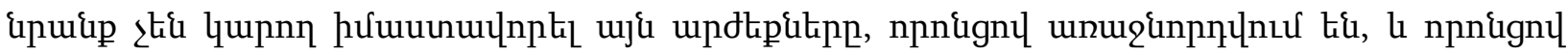

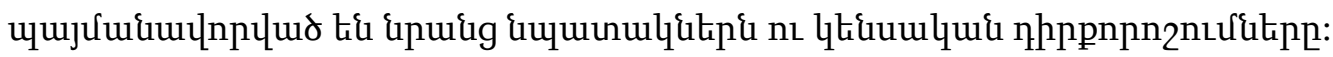




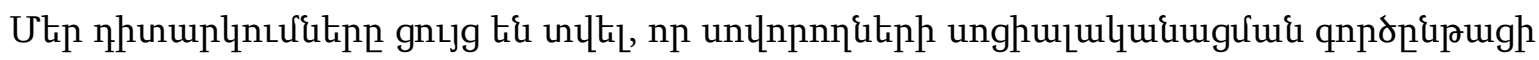

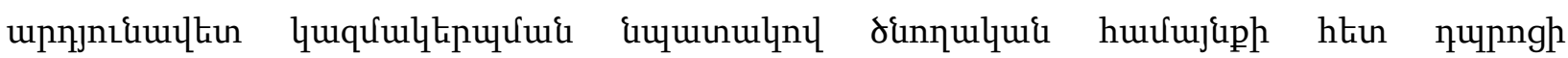

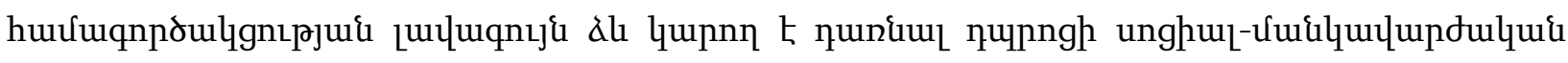

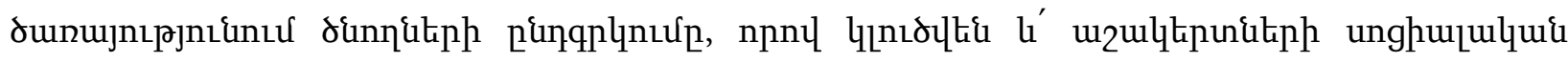

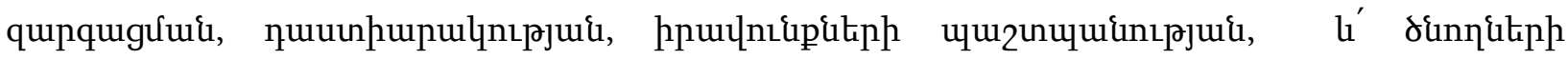

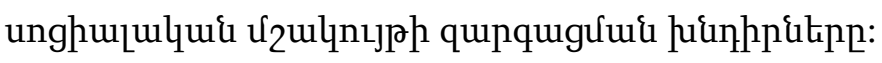

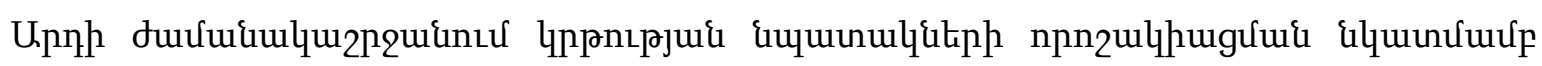

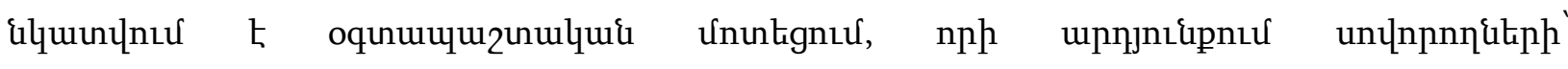

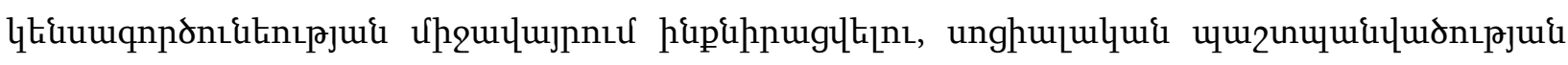

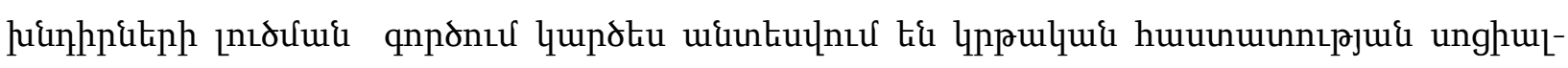

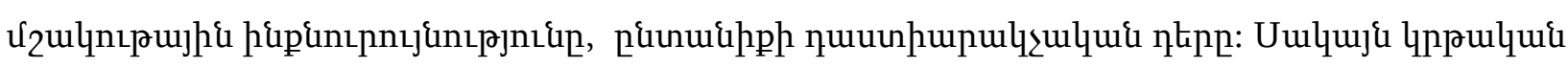

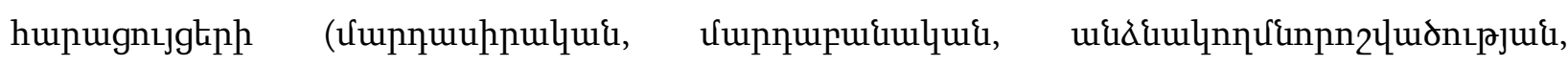

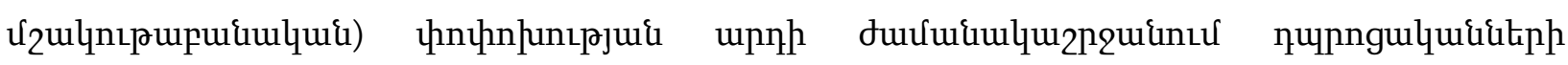

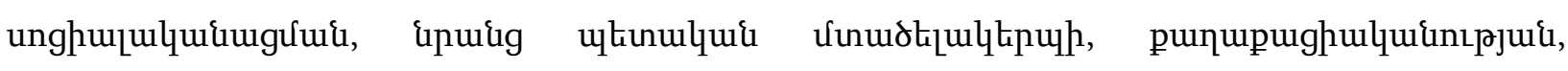

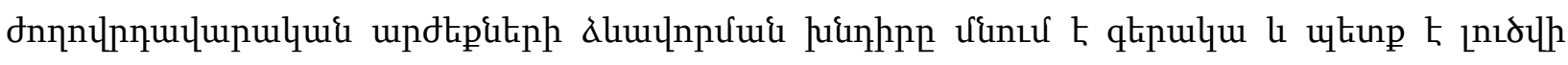

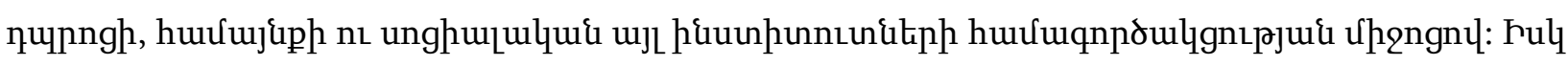

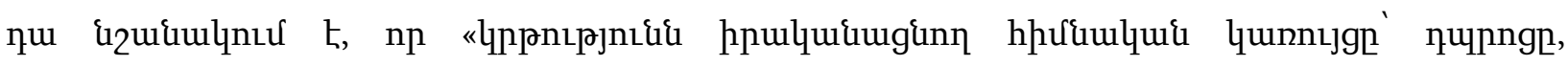

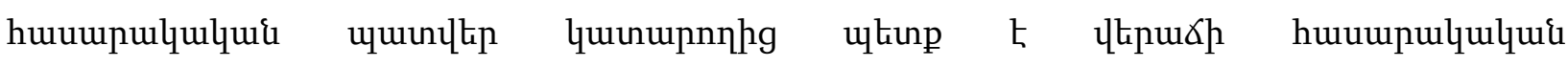

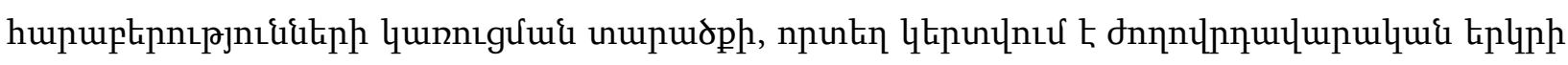

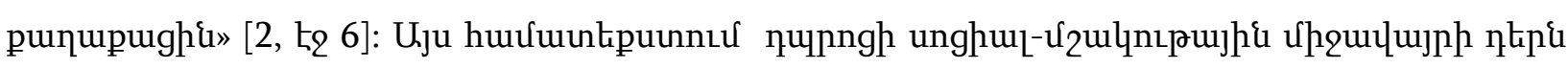

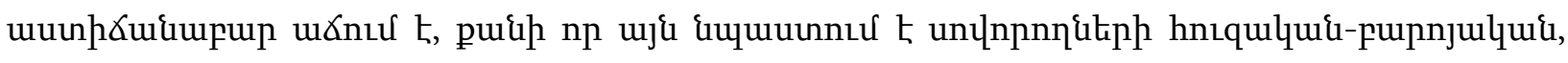

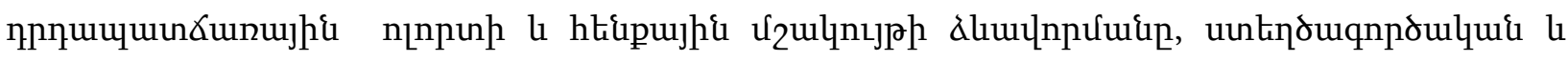

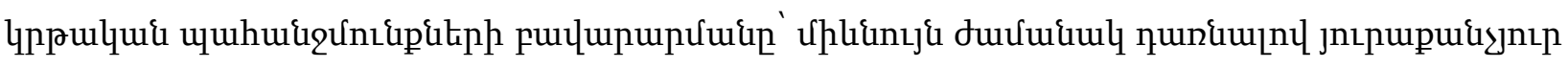

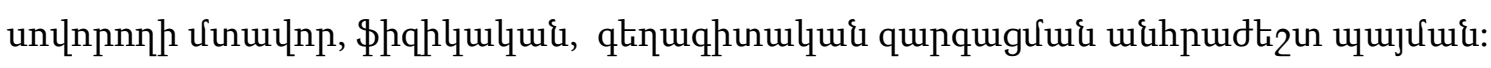

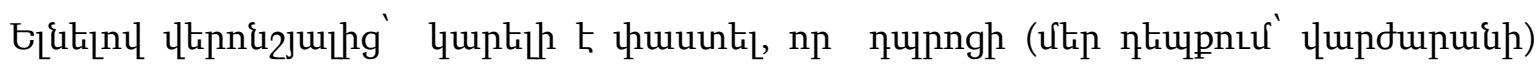

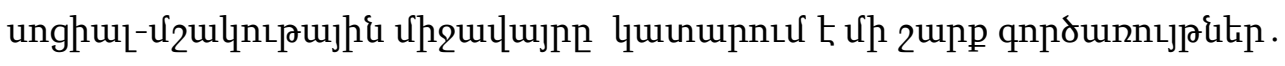

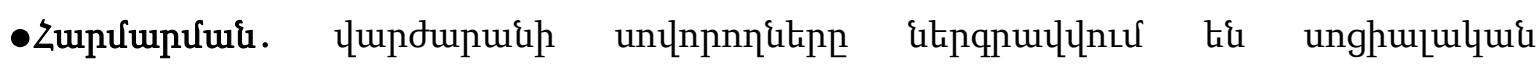

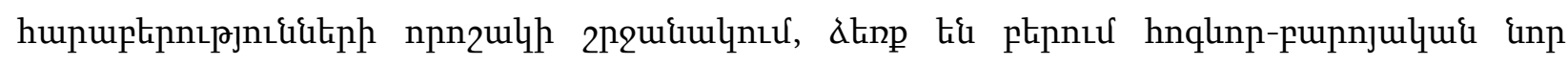

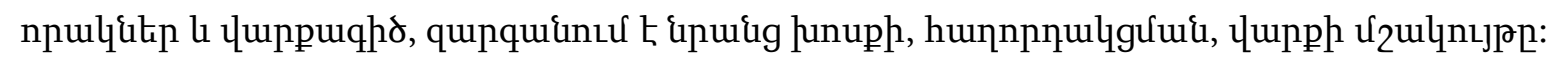

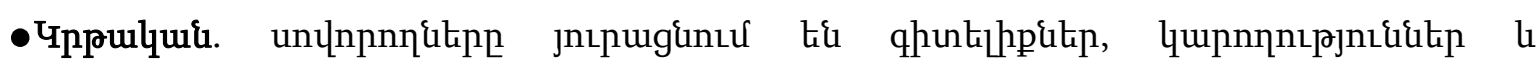

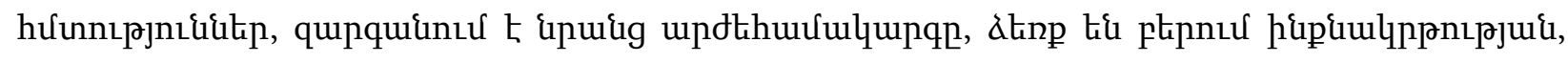

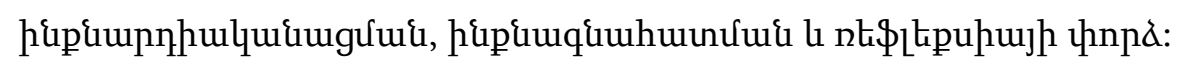

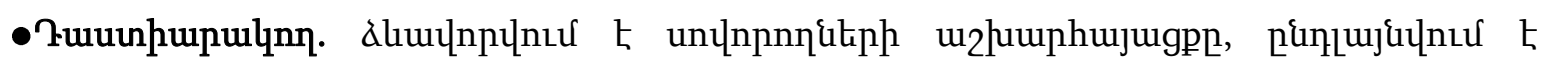




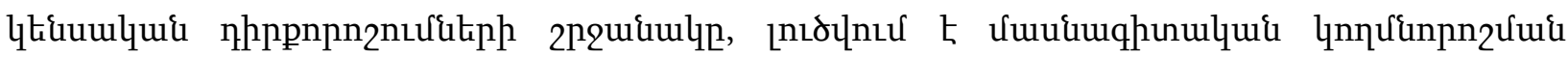

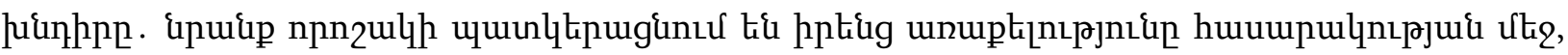

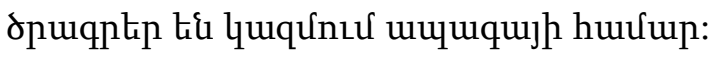

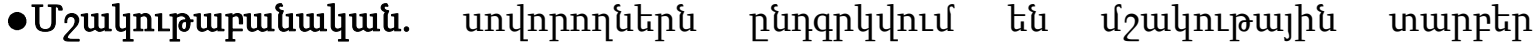

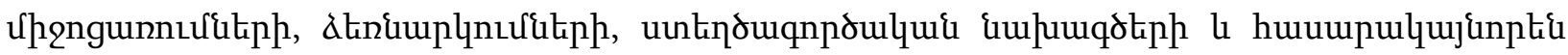

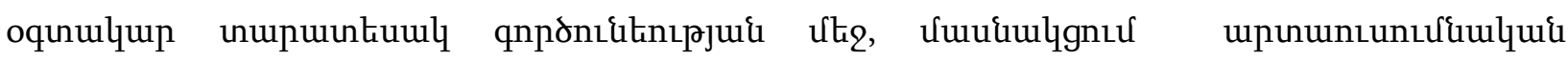

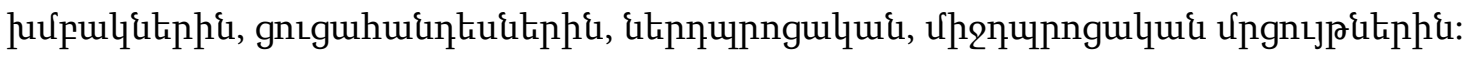

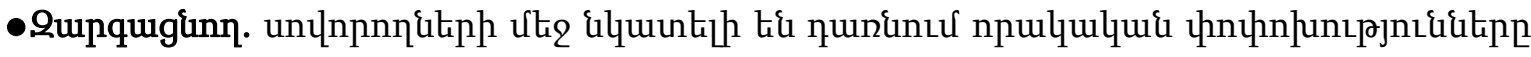

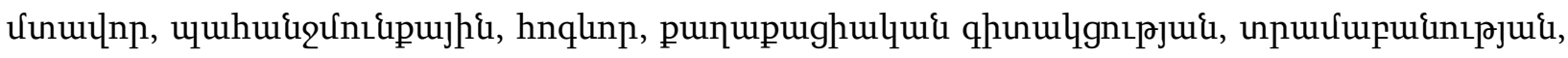

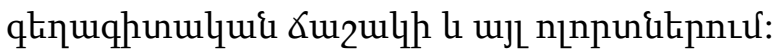

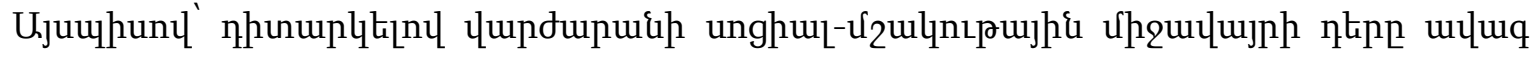

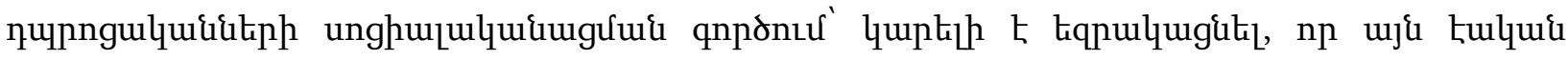

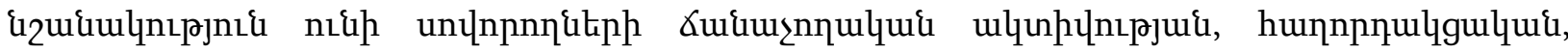

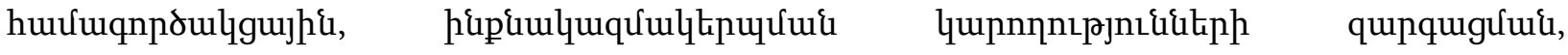

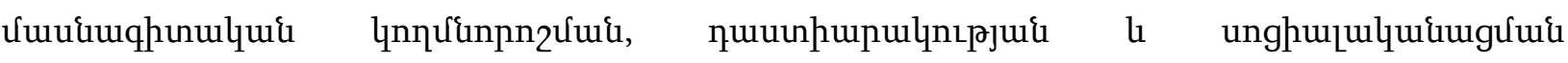

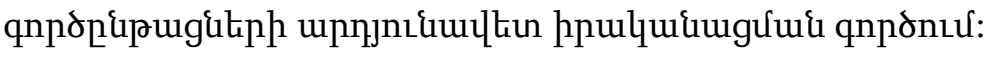

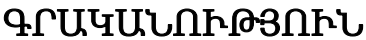

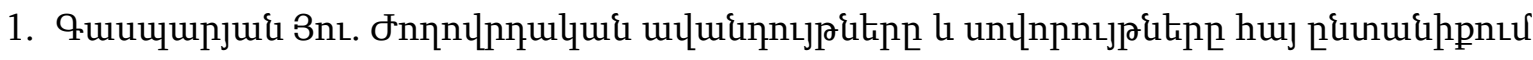

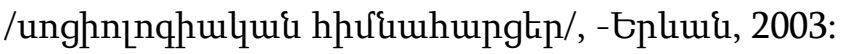

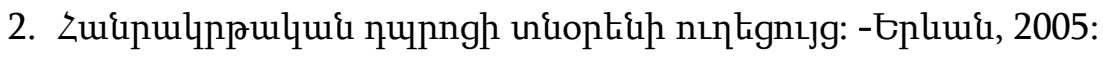

3. Леонтьев Д.А. От социальных ценностей к личностным: социогенез и феноменология ценностной регуляции деятельности.//Вестник МУ. серия 14: Психология.-Номер: 1, Год издания: 1997.

\section{THE ROLE OF THE SOCIO-CULTURAL ENVIRONMENT OF THE SCHOOL IN THE SOCIALIZATION OF SCHOOLCHILDREN}

The article examines the influence of the socio-cultural environment of the school on the socialization of senior students. A general characteristic of the structural components of the sociocultural environment of the school is given, its functions are determined and characterized. The influence of the socio-cultural environment on education, upbringing, socialization and development of students is substantiated.

Keywords: socialization, socio-cultural environment, high school, cognitive activity, 
communication, cooperation, self-organization, professional orientation 